\title{
The Distressed State of Colonial Indian Muslim Women Writers
}

\author{
Asma Siddiqui* \\ Jamia Millia Islamia University, House Number-24/2, 3rd Floor, Lane Number-36, Zakir Nagar, Okhla, New Delhi, India
}

*Corresponding Author

Asma Siddiqui

Article History

Received: 17.06 .2020

Accepted: 25.06 .2020

Published: 30.06 .2020

\begin{abstract}
My study aims to understand the distressed state of Colonial Muslim Women as doubly marginalised, scrutinizing the space of the obscure women writers as a site of analysis. The proposal intends to delve into the "Islamic feminism" through the life and works of Ashraf Bibi, Sultan Jahan Begum, Rashid Jahan, Iqbalunnisa Hussain, Begum Shaista Ikramulla as tools to show how the practices in the name of religion, the misguided interpretation of prophetic teachings and the old customs was the main cause for the backward position of Muslim women and not Islam which came as a reformation religion in the age of ignorance (Jahiliyyah).
\end{abstract}

Keywords: Islamic Feminism, Patriarchy, Religion, Education.

\section{INTRODUCTION}

Edward Said argues that "For Europe, Islam was a lasting trauma" as the Muslims took pride in their customs and traditions hence did not easily accept the 'infantile language'-English and the idea of the West civilizing the Muslim community [1]. The site of resistance to the imposed western notion of progress led to returning to the scripture as the uncontaminated vessel of Islam which brought several interpreters of the Quran. Furthermore, the interpreters which laid the absolute ways for women's idea of living in British India. Chirag Ali who developed a book called "The position of Women" in 1883 that talks of the rights of women based on Quran that says in Arabic "Iqra" meaning to read and educate oneself as the Prophet himself encourages "seeking knowledge is compulsory for every Muslim" and hence talks of the egalitarian point of view in Islam. The other type of interpreters being those whose patriarchal authority was formed by the ethics within the limits of a historically specific set of formation, delimited the "moral subjectivation"(Foucault) and believed knowledge is not "obligatory" for Muslim women .Leader like Sir Syed Ahmed Khan and Mohammad Iqbal though in favour of promoting education felt that little education for Mohammaden females is enough for "domestic happiness" as also agrees by Maulana Ashraf Ali in his book "Bahist Zewar[2,3]". The ideology of such leaders was moulded according to the time they lived in, where the idea of women's higher education did not even prevail as professor Farooq adds "The curriculum and organization of madaris were devised in a way that women were automatically being considered ineligible for higher Islamic education [4]".

The question of keeping the tradition alive by ulemas/maulvis and to stay in pace with the western ideas led to much turmoil in the Islamic sector and the "plea of inefficiency" was felt in the whole community as noticed by Rokeya Hussain in 1835. More than thousands of madrasas were established in the Mughal reign, yet the introduction of English language led to the decline of Islamic learning as the British did not provide jobs to people who learned from such Muslim institutions. However, a group of leaders including Sir Syed Ahmed Khan came up with the middle path, reconciling religion with secular education and founded the All Indian Mohammaden Educational Conference in 1886 for the 'duniyawi taleem' [5-8]. How the rise of education was inversely proportional to the decline of "taqlid" i.e. one man as the head interpreter is what the paper tries to lay the foundation on. The study aims to decode how the dominance of male which led to the confinement of Muslim women also led to the "diagnostic of power" by the women's agency when education not only enlightened the male but also the women in the time where non-western Muslim women were portrayed by the orientalist as bound by the unbreakable chain of religious oppression. In the year 1896, the question of Muslim women education was raised far and wide, which later founded reform parties to advocate "modern education

Copyright @ 2020: This is an open-access article distributed under the terms of the Creative Commons Attribution license which permits unrestricted use, distribution, and reproduction in any medium for non commercial use (NonCommercial, or CC-BY-NC) provided the original author and source are credited. 
among Muslim women and to say goodbye to immovable maulvis" as said by Chand Begum of Madras in 1903. With such changes taking place one may say that "Repetition" as said by Deleuze did not mean "repeat" but to "begin again, to renew, to question and to refuse" old age traditions and customs where "becoming" was not decided by "some already determined fixed viewpoint" (Heidegger) but by the tool of "Etihad" (critical thinking) and reinterpretation of Quran and Prophetic teachings to restore the egalitarian message of Islam[9].

As argued by Derrick Bells in his "interest convergence theory" how the dominant group (West) supports the subaltern (brown women) and save them from the oppressor (brown men) only when the West benefits from it in the process. The West profited from the patriarchal authority of Islamic interpreters that led to double talk where women belonged to men like Abul Ali Madudi who created Jamat-e-Islami in 1941 to bring Islamic laws as the way of life, believed "women's visibility"in public life as a sign of immorality which gave way to the West to bring in "Femonationalism I" (Sara R. Farris) and promote anti-Islamic sentiment. Muslim women who veiled themselves were taken as for the submissive victims of patriarchal religious culture, the other who did not conform to the traditional model was appreciated as of "Magrib" (West) origin. As Claude Gilliot in his "Exegies of the Quran" agrees the West justified their "attack on Islam and Muslim cultures by suggesting that their colonial civilizing mission was intended to free the poor oppressed women in Islam", this led to the double marginalization of women in Colonial India [10].

The paper talks heavily on how the fabric of oppression and bitter aporia of doom faced by the Muslim women of British India as doubly marginalized by the manmade traditions, wrong interpretations and further by the west who made them feel and look like the "other". With the coming of education for women the space that was left like void started to fill by women writers who wrote about their oppressed condition and how they overcame most of the obstructions. The fictional texts and essays I will be tracing shows how the human element is vanquished deliberately by the people in charge. Bibi Ashraf once told her relatives "When I learned to read and write my uncle got very angry with me" in her essay "How I Learned to Read and Write" 1899 and likewise "God gives Man robs" by Hossain have common end where they critique patriarchal mainstream interpretations of Islam[11]. When analyzing the works of colonial India, the common tension that arises in the work of women like Sultan Jahan Begum and Rokeya is the strong opposition to the "imitation of western custom and tradition" because to copy is to subdue as Jahan argues" take the good and discard the evil" meaning to acquire knowledge that the West provides and impart it to the people, further as said by Rokeya "We may enlarge and widen it(womanhood) thus increasing its excellence but what we should avoid is its total neglect and a tendency to slavish imitations of Western custom and tradition". Hossain in 1905 wrote Sultana's Dream which explores how 'women's mental slavery' and 'men's selfishness' are the main factors of women's oppression. She rightly says, "There is a saying 'Man proposes, God disposes' but my bitter experience shows that God gives, Man robs". Rokeya's protagonist's sister Sarah works in a laboratory, the fiction, therefore, giving the illusion of being a utopia of the feminist world only to reveal bitter dystopic spaces of the Muslim patriarchy very much present in society. Iqballunisa Hussain in her novel Purdah and Polygamy: Life in an Indian Muslim household, 1994 emphasizes on the 'submissiveness' and 'ignorance' felt by the women characters which lead to the 'self-importance' felt by male characters of the book[12]. Hussain whom herself lived in orthodox society got married at fifteen and it is only later when she received higher education that she realizes the fact that "The Purdah in the real sense of the world is not so much physical as it is moral". The two main centers of Muslim reformist movements was North India established its intellectual tradition and Muslim Bengal in which the Muslim sisters have been more undervalued than their Hindu sisters in nationalist discourses. Women writers like Akhtar Mahal Syed Khatun (1901-1928) though born in an educated aristocratic family remained hidden in history because the tradition did not allow women to go to school or college and bringing their work in public to be recognized was not even thought about [17]. With art and education flourishing around her yet she could not stop herself from getting married at the age of fourteen to someone whom she was engaged to marry long time ago, marriage then was as good as being sent to exile. The unhappiness of her life reflected in her work where characters like Ayesha of "Niyantrita" and Hasenara of "Menan Baran" are very unhappy characters that read books, write and were frequently told off for these activities.

The study also decodes the relationship of dependency in marriage which is not necessarily a relation of subjugation or loss. The women alone could not have come out of the darkness of double patriarchy in the age of transition. We come across men/husband who led women/wife out of the darkness of wrong interpretations and patriarchal discourse in colonial India. Sheikh Abdullah, husband of Waheed Jahan Begum who helped and motivated his wife writing "Khatun" in 1904 that promoted women's education and equality. Begum Rokeya though born in a conservative Bengali family where the sons received privileged education and the daughters were tutored in Arabic and Urdu privately, she was fortunate to have male supporters like brother Ibrahim who taught her English secretly, and husband Khan Bahadur who exposed her to the western knowledge and learning. While tracing example of such male supporters in the Delhi Sultanate, Itutmish the Sultan of Delhi appointed his daughter Raziya Sultan to lead the reign saying "My sons are incapable of leading and for that reason, I have decided that it is my daughter who should reign after me." Men like them reflect the image of Prophet who encouraged Muslim women to get the "horizontal equality" which helped the women in "the possibility of its undoing" (Butler) the tag of victims given to them by the West. The women of 
Prophet's world gave the best example of "positive" freedom, where Khadijah the first wife of Mohammad was the richest trades woman of Mecca, who attained self-mastery, had great wisdom and understanding [16].

Aishah the youngest of Prophet's wife was a hadith narrator, scholar, intellectual and jurist of great understanding. Islam not only removed ignorance in society but has promoted Musawah (equality) and honor to all members of society. Hence placing restrictions on women's education is the result of a misunderstanding of Islam and shariah, if not a willful act of keeping Muslim women on a tight leash. When the Prophet himself said (Arabic)' Women are equal in men' Now what happened in the last past four hundred to five hundred years is that tradition has mastered society and some people have mixed sharia, Islam and tradition to bring the women down. The Quran was written one hundred years after the Prophet died; its suras and hadith (the interpretation of the Prophets word) reflect the times more than they do the holy man. Definitions are the heart of interpretation and part of the path for gender-inclusive implementation. Therefore, the use and abuse of the word 'Islam' is politically charged. The one major solution to the problem is that women qualify themselves enough to decide which path to follow with no need of guidance. Because Islam does not believe in the mediator, individuals are responsible for their acts and deeds.

Parallel to the Muslim women writers who while critically engage in Islamic tradition had a firm belief in Islam as a solution, strongly condemning human language as an imperfect medium for harmful meanings which lies not with God but with the interpreters, we also come across Muslim women like Zeenuth Futehally who wrote: Zohra, 1951 and Tasleema Nasreen whose common end is to blame Islam as the problem. Such individuals whose "culture are rooted in some western tradition"( Adrienne Rich) are swimming in a set of ignorance because Quran plainly explains in chapter 35 verse 33".....the man and women who engage much in God's praise For them has God prepared forgiveness and a great reward ".The 'dominant ideology' as talked by Althusser in his book "Ideology and Ideological State Apparatus" was molded by the privileged strata of society in colonial India were acting in the name of God rather became a curse more than a blessing and the lower strata did not have voice enough to be heard and eventually followed what was told but lately with the principles of Islam in the hands of right interpreters and the rise of literacy we have Muslim women as then the fortunate few but now it includes women from all walks of society to show the right guidance of Islam[17]. Community is based on individuals and the self is the truth. The Islamic Path has been a long journey where every individual is responsible for his/her ways and this fact will not vanish because "as you sow, so shall you reap" but how we eventually walk down the path is up to us.

\section{REFFERENCE}

1. Armstrong, S. (2014). Uprising: A New Age is Dawning for Every Mother's Daughter. Macmillan.

2. Baveja, M.R. Women in Islam. The Institute of the Middle East Cultural Studies.

3. Browning, Don, S. (2006). Sex, Marriage \& Family in World Religious. Columbia UP.

4. Carroll, Theodora Foster. (1983). Women, Religion, and Development In The Third World. Praeger Publishers.

5. Delamotte, E. (1997). A Global Anthology of Women's Resistance. Routledge.

6. Hasan, M. M. (2012). Marginalisation of Muslim Writers in South Asian Literature: Rokeya Sakhawat Hossain's English Works. South Asia Research, 32(3), 179-197.

7. Hidayatullah, A.A. (2014). Feminist Edges of the Quran. Oxford UP.

8. Holm, J., \& Bowker, J. (Eds.). (1994). Rites of passage. A\&C Black.

9. Madhavananda, S., \& Ramesh, C.M.(1953). Great Women of India. 1st ed., Swami Gambhinaranda.

10. Narayana, A., \& Bandana, P. (2009). Living Our Religions: Hindu and Muslim South Asian American Women Narrate Their Experiences. Kumarian Press.

11. Majumdar, R. C. (Ed.). (1953). Great women of India. Advaita Ashrama.

12. Roy, O.(2004). Globalised Islam: The Search for a New Ummah. Hurst \& Company.

13. Sharma, A. Women in Indian Religion. Oxford University Press.

14. Souza, E.D. (2004). Purdah an Anthology. Oxford UP.

15. Stowasser, Barbara Freyer. Women in the Quran, Traditions, and Interpretation. Oxford UP, 1994.Print.

16. Women in Colonial India. (1989). Essays on Survival, Work and the State. Oxford University Press, Walton Street.

17. Yamani, M., \& Allen, A. (Eds.). (1996). Feminism and Islam: legal and literary perspectives. NYU Press. 